\title{
PROCEEDINGS OF THE FIFTY-THIRD ANNUAL MEETING OF THE AMERICAN SOCIETY FOR CLINICAL INVESTIGATION, INC., HELD IN ATLANTIC CITY, N. J., MAY 1, 1961
}

\author{
Presidential Address
}

\section{THE SHAPE OF CLINICAL INVESTIGATION}

\section{By CLEMENT A. FINCH}

It is customary and it seems to me appropriate for the President of our Society to devote his address to some general aspect of clinical investigation with which our Society is concerned. Past presidents have described changes which have occurred in contemporary medicine and research. I intend to speak briefly on the same theme; and if what I have to say should have scant merit, it shall at least have this virtue: that it was a footnote to what had been said by my capable predecessors.

However, a word first about the basic nature and needs of clinical investigation, since these are not subject to change. There is first the individual of keen mind and dedicated purpose and second, an environment in which such a person may work with a minimum of coercion and prejudice and a maximum of inspiration. These needs have been served best in the great universities, where creative scholarship has been catalyzed through associations of men of many academic disciplines engaged in the pursuit of truth. Such spawning beds as these for the clinical investigator must be considered inviolate. If we are agreed that these are the fixed requirements in our discipline, may I now proceed to consider first in broad outline the changes occurring in clinical investigation.

I. Change in clinical inc'estigation effected by increased financing. The external appearance of clinical investigation has in recent years undergone a metamorphosis in experimental paraphernalia and the number of its devotees. This has been due largely to financing, a reflection not only of our affluence as a nation, but also of the increased support from a public awakened to the accomplishments of medical research. During the last twenty years, total appropriations for medical research have increased from 40 to over 700 million dollars per year, and federal support has increased from 7 per cent in 1940 to over 50 per cent of the total appropriations at present. During the same interval the number of physicians employed as teachers and investigators is estimated to have increased by one and one-half times (1). These figures indicate that the resources available to the individual investigator have increased approximately tenfold. It has meant what we are all well aware of: a growth of research units bristling with technical personnel and equipment.

Under this sponsorship we see the emergence of the professional investigator, the man who has set out to make a career of research and who is eminently qualified to take advantage of the facilities at his disposal. By contrast, the more amateurish scientist, unprepared for this transition, has often floundered, exhausting his energies on complicated instruments which he has been unable to control. It is equally important, however, that this new brand of trained investigator should have an understanding of clinical medicine if he is to concern himself with human disease; else his so-called clinical research may become perverted to elegant but irrelevant laboratory studies. The difficulty of riding these two horses of clinical and laboratory know-how is surpassed only by the opportunities offered. In the programs of these three societies there is ample testimony of the effective application of basic science to clinical problems which has become possible through modern facilities and subsidized training. The speed of modern communication and the resources available to him also permit the investigator to seek out unusual clinical opportunities, regardless of their geographic location. This span of research activity is well illustrated by the recent studies of abnormalities in hemoglobin synthesis which extend from the chemical dissection of the amino acid sequence of the molecule through clinical manifestations and on to population genetics. There is truly a spacious arena for research before us. In the past the clinical investigator had more severe limits and therefore often applied himself to a diversity of clinical problems which increased the breadth of his medical knowledge. Today project-jumping is wasteful and greater contributions are generally made by examining the many dimensions of a single subject. This change in shape from the broad and limited approach to the study in depth is a natural one for the investigator. With all of this have come as well certain obligations :

II. New responsibilities incurred by the scientist. While it is fine to discuss what money has done, one should be mindful that the success of this high finance in research depends to a considerable degree on its administration. The National Institutes of Health have been placed in a position of responsibility in this connection. It is appropriate that we acknowledge the skill and wisdom with which the administrative staff of the Public Health Service has managed this funding program. It has been accomplished without infringing on the integrity of academic institutions or the independence of the individual investigator. In the general program one might underline the emphasis which has been placed on support of the man through career investigatorships and long-term general support, and on support of clinical facilities in the form of special research wards, where 
studies on man may be carried out under optimal conditions. These measures have provided solidity to the new form of clinical investigation. The system of reviewing research and training projects relies heavily on advice by scientific consultants and has operated in such a manner as to win the confidence of the scientific community. Its merit, I believe, lies in the number of competent scientists who are continually rotating on its panels. I am unconvinced that one acquires better vision in the selection of productive and creative work through prolonged exposure to the task of grant selection; rather, experience hardens the artificial criteria by which requests are excluded. At any rate, the procedure by which deserving grant requests are matched with available funds is a democratic process in which I believe we should accept and indeed cherish our responsibility to participate.

Federal support of research also brings the public at large into closer relationship to the scientist. This relationship requires, on the part of the scientist, a conscience sensitive to the health needs of the people, and on the other hand, an understanding by the people of the nature of basic and applied research. The distortion of communication of scientific information to the public is a matter of serious consequence, for it may lead to faulty opinions by the public as to how and where research should be pursued. Such faulty opinions may gain expression through the undue direction of appropriations and an attempt to deploy scientists to special objectives. Problems arise through lack of understanding rather than through any difference in ultimate objectives of scientist and public. There is need for better understanding of the limitations and wastefulness of crash programs and the importance of cultivating the new idea which cannot be planned. We cannot escape the necessity of improving the transmittance of both the facts and philosophy of research to the public if clinical investigation is to proceed along orderly lines.

III. Effects on the Society. I will conclude with a few remarks on the relation of the American Society for Clinical Investigation to this remodeling process. The product of consequence of our Society lies in the bibliographies of our members and we should express satisfaction in the activities of our journal in which these studies ultimately find their place. The annual meeting constitutes a second medium of exchange of information. The pattern of our meetings undergoes continued modification to meet the expansion of research. This year in addition to the general session there were seven conjoint specialty sessions held with the American Federation for Clinical Research; and the total number of papers presented from our Society this year is 59 , or 28 per cent of the abstracts submitted. I do not believe that suitable attention has been paid in presentation of these papers to the difference in audience between the general and specialty sessions, and therefore have invited the essayists today to make their papers understandable to the general audience. While it has been held by most members that the formal activities of our Society be limited to the annual meeting and journal, it seems most appropriate that various groups be organized in association with these meetings which cross society lines in dealing with more specific matters of research importance.

The major concern of our Society in these years is the question of membership, as presented so clearly last year by Dr. Berliner. The changing shape of clinical investigation has forced two problems on us. The first is proper selection of candidates. As clinical research expands to encompass the facts and concepts of contiguous scientific disciplines, it becomes increasingly hard to compare individuals and to define specific merits in the clinical investigator. With Berliner, I would hope for the develcpment of an effective mechanism for scientific evaluation of candidates which would ease the heavy burden on your council. The second problem is that of numbers. The Society takes pride in the great distinction of its past members and strives for a similar standard of excellence in the future. It has been argued that to increase the number of new members elected each year would run the danger of lowering standards. The natural extension of this argument is a limited honorary society which ignores the growth of clinical investigation. Such a small society cannot easily embrace new currents of research and blocks unique individuals and those in overlapping areas of science from membership. Also, if one is forced to choose people who have already arrived, one may end up with a dignified society which is going nowhere. I realize that the last statement is a provoking one, but I cannot believe that this Society has adequately met the challenge of expansion and change in contemporary investigation and would personally urge an orderly adoption of appropriate increases in membership. The proposed change in constitution to be voted on today would provide a step in that direction.

\section{REFERENCE}

1. Federal Support of Medical Research. Report of the Committee of Consultants on Medical Research to the Subcommittee on Departments of Labor and Health, Education, and Welfare of the Committee on Appropriations, United States Senate, Eightysixth Congress, Second Session. May, 1960. 


\section{PAPERS PRESENTED AT THE FIFTY-THIRD ANNUAL MEETING 1961}

1. On the Site of Viral Interference. Monto Ho, Pittsburgh, Pa. (introduced by Maxwell Finland). (1049)

2. The Relative Abundance of Viral Receptors: An Explanation of the Differential Susceptibility of Suckling and Adult Mice to Coxsackie $B_{1}$ Infection. Calvin M. Kunin and Norma E. Halmagyi, Charlottesville, Va. (introduced by William S. Jordan, Jr.). (1055)

3. Pyrimidine Biosynthesis in Man: Suppression In Vivo by Anti-neoplastic Agents. Mitchell RabKin, Elizabeth Frederick, Myron Lotz and Lloyd $H$. Smith, JR.,* Boston, Mass. (1073)

4. Leukemic Cell Proliferation as Determined by In Vitro Deoxyribonucleic Acid (DNA) Synthesis. Charles G. Craddock * and George S. Nakai, Los Angeles, Calif. (1031)

5. Abnormalities of Erythrocyte and Plasma Lipids in Acanthocytosis. Peter Ways, Claude F. Reed and Donald J. Hanahan, Seattle, Wash. and Rochester, N. Y. (introduced by Cyrus E. Rubin). (1088)

6. Active Transport of Iron In Vitro by Duodenal Segments and the "Mucosal Block." James G. MANIS and David Schachter,* New York, N. Y. (1060)

7. Response to Repeated Platelet Transfusions from the Same Donor. Emil J. Freireich, Allan Kliman, Lawrence A. Gaydos and Leslie R. Schroeder, Bethesda, Md. (introduced by C. Gordon Zubrod). (1039)

8. Bile Acid Fever and Inflammation in Man. Robert H. Palmer, Paul B. Glickman and Attallah Kappas, Chicago, I1l. (introduced by Richard L. Landau). (1069)

9. Myocardial Blood Flow as Indicated by the Disappearance of $\mathrm{NaI}^{181}$ from the Heart Muscle. William Hollander, Irving M. Madoff and Aram V. ChoBanIAN, Boston, Mass. (introduced by Robert W. Wilkins). (1050)

10. Genetic Control of the Ability of Human Blood to Neutralize Angiotensin and Its Relationship to Essential Hypertension. J. Edwin Wood,* Augusta, Ga. (1090)

11. The Influence of Arterial Pressure on the Antihypertensive Action of a Normal Kidney, a Biological Servomechanism. Louis Tobian,* Beverly WinN and Jeanette Janecek, Minneapolis, Minn. (1085)

12. Relationship of Bacteriuria to Hypertension: An Epidemiological Study. Edward H. Kass,* William E. Miall and Kenneth L. Stuart, Boston, Mass., Penarth, Wales and Jamaica, W. I. (1053)

13. The Alveolar Diffusing Volume and the Water Space of the Pericapillary Tissues of the Lungs as Measured by Multiple Indicator Dilution Curves. LLOYD Ramsey, W. Puckett, A. Jose and W. Lacy, Nashville, Tenn. (introduced by C. R. Park). (1074)

\section{* Member.}

( ) Page number of abstract.
14. Dominant Role of Pulmonary Vascular Engorgement as a Determinant of Dyspnea. H. PAGe Mauck, JR. and William Shapiro, Richmond, Va. (introduced by John L. Patterson). (1061)

15. The Determination of Intracellular $\mathrm{pH}$ in Normal Human Subjects. Eugene D. Robin,* Philip A. Bromberg and Robert J. Wilson, Pittsburgh, Pa. (1076)

16. Evidence for a Renal Tubular Amino Acid Transport System Common to Glycine, L-Proline and $\mathrm{Hy}$ droxy-L-proline. Charles R. Scriver, Irwin A. Schafer and Mary L. Efron, Montreal, Canada and Boston, Mass. (introduced by John C. Beck). (1080)

17. The Effect of Blood Glucose on Circulating Bound and Free Insulin. Harry N. Antoniades, Kare Gundersen and Hugh Pyle, Boston, Mass. (introduced by Charles A. Janeway). (1022)

18. Relationship of Sulfhydryl Inhibitors and Reductive Conditions to the Action of Insulin on Adipose Tissue. W. S. Lynn, Jr.,* Eugenia Earnhardt and Rose Brown, Durham, N. C. (1059)

19. Effects of $\mathrm{PCO}_{2}$ and $\mathrm{pH}$ on the Plasma Binding, Turnover, and Tissue Uptake of Thyroid Hormones. Milton W. Hamolsky * and Myron Stein, Boston, Mass. (1047)

20. Alterations in Steroid Hormone Secretion Produced by Inhibition of Cholesterol Biosynthesis. JAmes C. Melby, Marlyn St. Cyr and S. L. Dale, Little Rock, Ark. (introduced by Richard V. Ebert). (1063)

21. Mechanism of the Anabolic Effect of Testosterone. J. D. Wilson, Dallas, Tex. (introduced by Marvin D. Siperstein). (1088)

22. Antidiuretic Hormone-like Effects of Adenosine-3',5'phosphate (Cyclic AMP) and Theophylline in the Toad Bladder. JACK OrlofF* and Joseph HaNdLer, Bethesda, Md. (1068)

23. Human Serum Growth Hormone: Measurements of Concentration and Turnover with a Radioimmunoassay. Robert D. Utiger, Mary L. Parker and William H. Daughaday,* St. Louis, Mo. (1086)

24. The Mechanism of Aldosterone Stimulation Following Hemorrhage in the Hypophysectomized Dog. PAtrick J. Mulrow and William F. Ganong, New Haven, Conn. and San Francisco, Calif. (introduced by J. W. Hollingsworth). (1065)

25. Biochemical Detection and Histological Study of Muscular Dystrophy in the Preclinical Stage. CARL M. Pearson, Sudhir R. Chowdhury and William M. Fowler, Los Angeles, Calif. (introduced by William N. Valentine). (1070)

26. The Effects of Guanethidine on Triiodothyronineinduced Hyperthyroidism in Man. Thomas E. GAFFNey and Eugene Braunwald, Bethesda, Md. (introduced by Robert W. Berliner). (1040) 